\title{
G20 Note On Environmentally Sustainable Investment For The Recovery
}




\section{G20 NOTE ON ENVIRONMENTALLY SUSTAINABLE INVESTMENT FOR THE RECOVERY}

IMF staff regularly produces papers proposing new IMF policies, exploring options for reform, or reviewing existing IMF policies and operations. The Report prepared by IMF staff and completed on April 1, 2021, has been released.

The staff report was issued to the Executive Board for information. The report was prepared by IMF staff. The views expressed in this paper are those of the IMF staff and do not necessarily represent the views of the IMF's Executive Board.

The IMF's transparency policy allows for the deletion of market-sensitive information and premature disclosure of the authorities' policy intentions in published staff reports and other documents.

Electronic copies of IMF Policy Papers

are available to the public from

http://www.imf.org/external/pp/ppindex.aspx

\section{International Monetary Fund \\ Washington, D.C.}




\section{INTERNATIONAL MONETARY FUND}

March 30, 2021

G20 NOTE ON ENVIRONMENTALLY SUSTAINABLE INVESTMENT FOR THE RECOVERY

\section{EXECUTIVE SUMMARY}

This note ${ }^{1}$ prepared for the $\mathrm{G} 20$ Infrastructure Working Group summarizes the main finding of the IMF flagships regarding the role of environmentally sustainable investment for the recovery. It emphasizes that environmentally sustainable investment is an important enabler for a resilient and inclusive recovery-it creates jobs, spurs economic growth, addresses climate change, and improves the quality of life. It can also stimulate much needed private sector greener and resilient investment.

\footnotetext{
${ }^{1}$ The views expressed in this paper are those of IMF staff and do not necessarily represent the views of the IMF, its Executive Board, or IMF management.
} 
Approved By

Paolo Mauro
Prepared by Suphachol Suphachalasai under the guidance of Manal Fouad and Chishiro Matsumoto (all FAD)

Environmentally sustainable investment ${ }^{2}$ is an important enabler for a resilient and inclusive recovery -it creates jobs, spurs economic growth, addresses climate change, and improves the quality of life. It can also stimulate much needed private sector greener and resilient investment.

\section{Environmentally sustainable public investment can mitigate the impact of climate change and foster resilient and long-term growth with quality infrastructure.}

\section{An environmentally sustainable infrastructure push would support the COVID-19} recovery and boost global GDP. According to the IMF World Economic Outlook October 2020 edition, a coordinated greener and resilient infrastructure push, supported by other mitigation policy measures to reduce greenhouse gas emissions, ${ }^{3}$ could boost annual average global GDP by 0.7 percent between now and 2035. Such a policy package is also necessary to achieve the Paris Agreement goals. However, it is important to acknowledge the principle of equity and common but differentiated responsibilities under the Paris Agreement-an environmentally sustainable public investment strategy and policy package should be tailored to country-specific circumstances, needs, and resource availability.

2. In the long term, environmentally sustainable investment and other mitigation policies would result in needed emission reduction and place the global economy on a stronger and more sustainable path. In the second half of the century, the benefits of greener and resilient infrastructure investment, combined with other mitigation policies, are expected to grow due to reduced climate damages. The economy would benefit from the avoided damages from climate change-such as lower productivity due to higher temperatures and more frequent natural disasters-leading to higher output relative to what it would have been without the policies. Based on recent estimates, the projected net output gains from limiting the global mean temperature increase to $2^{\circ} \mathrm{C}$ increase rapidly after 2050 , reaching up to 13 percent of global GDP by $2100 .^{4}$ Environmentally sustainable infrastructure investment would also bring about other development

\footnotetext{
${ }^{2}$ Environmentally sustainable investment is defined as an investment that is aligned with long-term climate resilient and greener growth. This includes investing in, among other things, climate-smart and/or low-carbon options, greener and resilient infrastructure, natural disaster preparedness and response, and measures that have positive impacts on the local environment (such as water and air quality) and natural resources (such as forests, ecosystem, and biodiversity). In this Note, we refer to "environmentally sustainable" and "greener" infrastructure interchangeably. The Note recognizes that the principle of common but differentiated responsibilities due to different national circumstances applies in the context of the Paris Agreement.

${ }^{3}$ Mitigation refers to a human intervention to reduce the sources or enhance the sinks of greenhouse gases (IPCC 2014).

${ }^{4}$ However, even these estimates are likely to understate benefits from mitigating climate change as they imperfectly take account of-or do not incorporate-some of the damages related to temperature increases such as a higher frequency and severity of natural disasters, a rise in sea levels, and the risk of more catastrophic climate change.
} 
co-benefits, such as improved public health due to better air and water quality, and recovery of biodiversity, forests, oceans and the broader ecosystems.

\section{Environmentally sustainable infrastructure underpins the quality infrastructure} investment agenda. Looking forward, planning for environmentally sustainable infrastructure will be a critical element of the global policy effort to realize the Paris Agreement objectives and achieve the commitments stipulated in Nationally Determined Contributions (NDCs) at the country level. The post-COVID recovery phase could be key to building the economy of the future and addressing heightening risks such as climate-related risks and natural disasters. The G20 Principles for Promoting Quality Infrastructure Investment reflect the group's common strategic direction and aspiration for quality infrastructure investment. Environmentally sustainable investment is consistent with Principle 3: Integrating Environmental Considerations in Infrastructure Investments and Principle 4: Building Resilience against Natural Disasters and Other Risks. ${ }^{5}$

\section{Environmentally sustainable public investment promotes employment and creates jobs.}

\section{Resilient and greener investment-led stimulus would raise global employment} significantly. Greener investment can create jobs and be an engine of economic growth, especially in the current context of accommodative monetary policy. A stimulus package, including both a large upfront greener infrastructure investment stimulus and complementary mitigation policy measures, would boost global employment by 12 million jobs on average each year over the next seven years. ${ }^{6}$ The environmentally sustainable infrastructure investment itself is estimated to increase the number of jobs by 32 million over the same period. Resilient and greener public investments will also add aggregate demand and employment now when it is most needed. Furthermore, greener infrastructure (e.g. power grid extensions to integrate renewable energy, electric vehicle charging stations) will enable the private sector to adopt new technologies more cost effectively and rapidly.

\section{Environmentally sustainable infrastructure investment creates more jobs than}

traditional sectors. Renewable-based electricity generation and energy efficiency improvement investments are more job-intensive than fossil fuel-based electricity generation. Expanding lowcarbon sectors, such as renewable energy, retrofitting of buildings, electric car production, and the services sector, are typically more labor intensive than the shrinking high-carbon sectors (such as fossil fuel energy, transportation, heavy manufacturing)—both in the short and long term-and can create many jobs (Figure 1). High-job-intensity greener investments include investments in greener electricity ( 8 jobs per US $\$ 1$ million), energy-efficient buildings (2-13 jobs), and greener water and sanitation through efficient agriculture pumps and recycling (6-14 jobs). ${ }^{7}$

\footnotetext{
${ }^{5}$ G20. 2019. G20 Principles for Quality Infrastructure Investment. July 2019.

${ }^{6}$ IMF. 2020. World Economic Outlook: A Long and Difficult Ascent. Washington, DC, October.

${ }^{7}$ IMF. 2020. Fiscal Monitor: Policies for the Recovery. Washington D.C., October.
} 
6. In times of uncertainty such as now, greener public investment boosts confidence and promotes private investment. According to the IMF Fiscal Monitor October 2020, environmentally sustainable public investments tend to have larger multipliers and higher job impacts during such period of high uncertainty. As many as 20-33 million jobs are expected to be created globally for 1 percent of GDP of public investment in advanced economies and emerging economies.

Furthermore, in these periods of high uncertainty, public investments including greener investments tend to have larger multipliers (i.e. the multiplier is above 2 after two years).

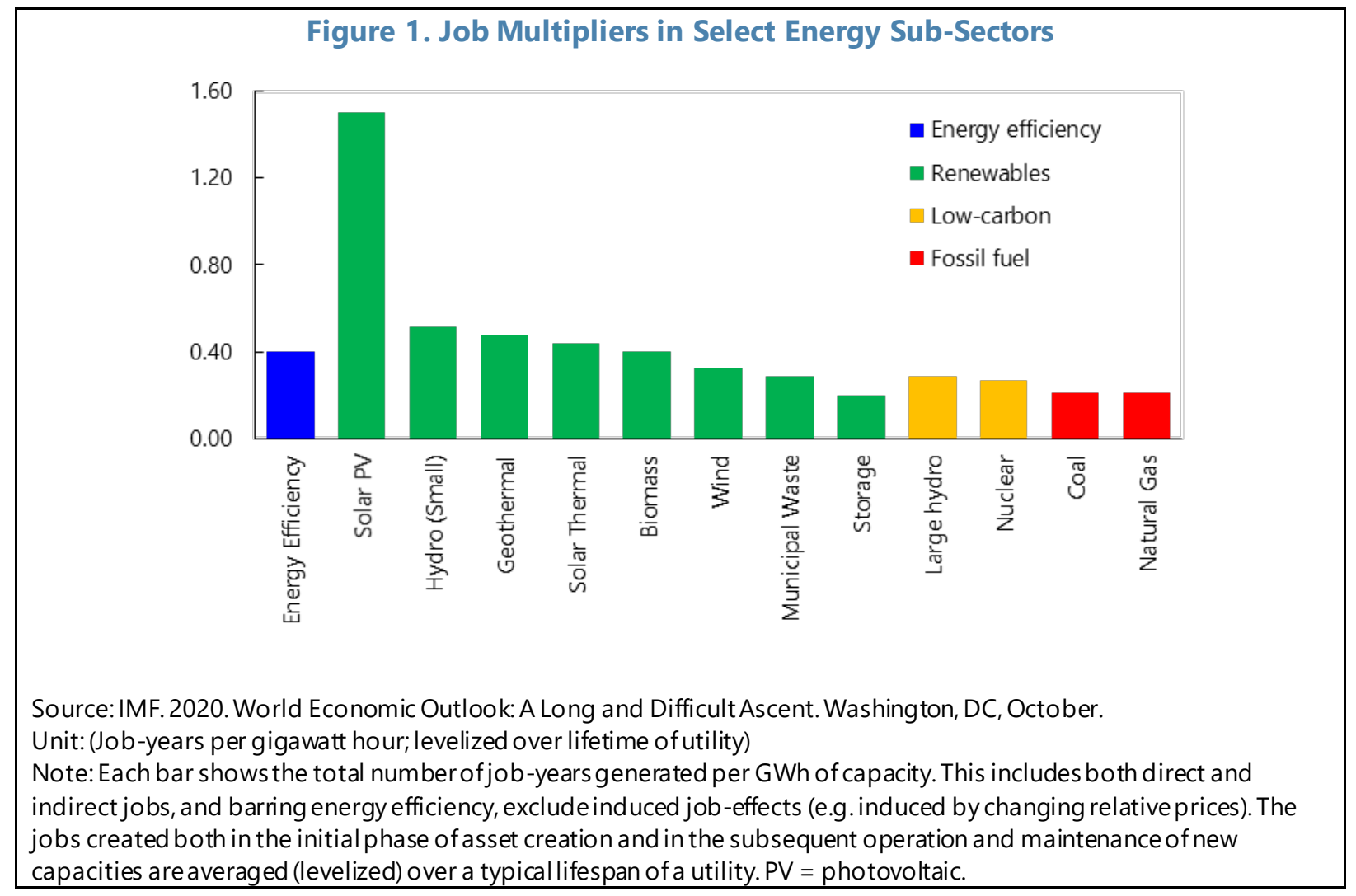

\section{Environmentally sustainable investment needs are large but beneficial in the long term.}

7. Large investments are needed to fill the infrastructure gap. A modern and wellfunctioning infrastructure has a truly transformative impact on the quality of life and economic growth. Low-income developing countries and many emerging market economies have looming infrastructure needs to provide clean water, affordable and reliable electricity, efficient and safe transportation, and reliable telecommunication services. Many advanced economies have aging infrastructures and see urgent needs for their upkeep and modernization. The infrastructure gap is large: global infrastructure investment needs are estimated to be US $\$ 94$ trillion by 2040 -equivalent to 3.5 percent of annual global GDP-based on the current economic trends. ${ }^{8}$ To achieve the Sustainable Development Goals (SDGs), an estimated 81/2 percent of GDP would be needed in 2030

\footnotetext{
${ }^{8}$ Global Infrastructure Hub and Oxford Economics. 2017. Global Infrastructure Outlook. July 2017.
} 
for infrastructure investments in roads, electricity and water and sanitation in low-income and developing countries (LIDCs), and about 3 percent of GDP in emerging market economies. ${ }^{9}$

\section{Resilient infrastructure investment pays off as benefits outweigh cost over the lifetime}

of investments. While the immediate costs of tackling climate change are relatively high, there is an opportunity now to deploy the next round of fiscal stimulus, including infrastructure investment, to boosts aggregate demand and employment, while promoting environmental sustainability.

- In low-income countries, additional needs for public investment for adapting to climate change and responding to natural disasters amount to about US $\$ 25$ billion per year (1.1 percent of annual GDP on average). ${ }^{10}$ Deep emission cuts to contain global warming to $2^{\circ} \mathrm{C}$ would require an increase of global energy infrastructure investment by $0.3-0.6$ percent of GDP per year on average over the next two decades, with the share of low-carbon energy supply rising from 40 percent in 2020 to 80 percent in 2050. ${ }^{11}$

- But there is a growing evidence that investing in resilient infrastructure pays off over time and improves long-term economic performance of investment, considering significant risks associated with climate change and natural disasters. It is estimated that every US\$1 invested in resilient infrastructure in low- and middle-income countries yields US $\$ 4$ in net benefits. ${ }^{12}$ The benefit-cost ratio of investing in resilient infrastructure in these countries ranges from 2:1 to 10:1, with the investments yielding multiple dividends of avoided losses, economic benefits, and social and environmental benefits. ${ }^{13}$ Investing in adaptation to climate change is also found to deliver high returns, often exceeding 100 percent (reaching 300 percent for the case of drought resilience and 1,200 percent for storm protection in Sub-Saharan Africa). ${ }^{14}$

9. The cost of inaction will also be high. Climate change and natural disasters are having adverse impacts on critical infrastructure around the world. Natural disasters cost about US\$18 billion a year in low- and middle-income countries through direct damages on infrastructure assets and impose US $\$ 391-$ US $\$ 647$ billion economic cost a year through service disruption. ${ }^{15}$ At the same time, many existing infrastructures (such as energy and industrial infrastructures, and buildings) are sources of a large amount of greenhouse gas emissions.

\footnotetext{
${ }^{9}$ Forthcoming IMF 2021 estimates.

${ }^{10}$ IMF. 2020. Fiscal Monitor: Policies for the Recovery. Washington D.C., October.

${ }^{11}$ IMF. 2020. Fiscal Monitor. IDEAS to Respond to Weaker Growth. Washington D.C., April; IMF. 2019. Fiscal Monitor: How to Mitigate Climate Change. Washington D.C., October.

${ }^{12}$ World Bank. 2019. Lifelines: The Resilient Infrastructure Opportunity. World Bank. Washington D.C.

${ }^{13}$ Global Commission on Adaptation. 2019. Adapt Now: A Global Call for Leadership on Climate Resilience.

${ }^{14}$ IMF. 2020. Fiscal Monitor: Policies for the Recovery. Washington D.C., October.

${ }^{15}$ World Bank. 2019. Lifelines: The Resilient Infrastructure Opportunity. World Bank. Washington D.C.
} 


\section{While public investment has a key role to play, a large fraction of environmentally} sustainable investment will have to come from the private sector. The private sector is also increasingly interested in environmentally sustainable infrastructure investment. In this context, it is key to ensure that correct price signals and other financial incentives are provided by governments to encourage greener and resilient private sector investment. It is also important to address the challenges created by the COVID-19 pandemic for private investment in infrastructure, such as supply chain disruptions and heightened macroeconomic turbulence, especially in developing and emerging markets. Given the scarce public resources relative to the total size of infrastructure investment requirement, key challenges include strategic use of public funds to leverage other greener financing sources and promoting environmentally sustainable practices in the financial sector. ${ }^{16}$ This implies a much more coordinated approach to the public and private sides to crowd in all possible financing sources, including efforts to improve regulatory certainty, greener asset class standardization, and resilience indicators to help incentivize private investment. ${ }^{17}$

\section{Strong public investment management is key to ensure timely and quality public investment in environmentally sustainable projects.}

\section{To successfully support the recovery, public investment needs to be timely while} maintaining project quality. As part of the economic stimulus, governments often rely on readily appraised and prioritized projects that can be executed immediately. However, countries may not have such projects adequately at hand and thus may not be able to ramp up public investment in time when needed. In this context, the October Fiscal Monitor gave priority to four steps : (i) invest right now on maintenance of existing infrastructure, (ii) review and restart good projects, (iii) create and maintain a pipeline of carefully appraised projects that can be delivered within a couple of years, and (iv) start planning for the new development priorities. These steps will not only help identify good investments that can be kick-started right away, but also prepare economies for the future. ${ }^{18}$

\section{The economic and social impact of public investment depend crucially on the} efficiency of public investment. On average, over one-third of public investment value is lost due to inefficiencies, and better public investment management-that is strong public sector institutions that effectively plan, allocate, and implement public investment-can reduce losses by more than

\footnotetext{
${ }^{16}$ A potential funding source that could help bridge infrastructure gap also includes long-term institutional investors with an estimated total asset under management of over US\$80 trillion globally (Swiss Re Institute and Global Infrastructure Facility 2021).

${ }^{17}$ Blended finance has emerged as a promising solution to fund climate resilient and low carbon infrastructure investments, through strategic use of public/concessional finance to mitigate investment risks, lower the cost of capital, and catalyze additional private finance that would otherwise not be available on commercial terms.

Furthermore, countries need to also build readiness to improve access to international climate finance and markets, while simultaneously making use of financial instruments such as green bonds and insurance mechanisms to support environmentally sustainable investment.

${ }^{18}$ Maintenance can be deployed quickly and has great benefits-it preserves substantial economic gains from investing in infrastructure. Prioritizing and restarting active projects would contribute to the timely delivery of a stimulus package. In addition, governments should take into account new development priorities that will lead to economic and social transformations beyond the recovery phase.
} 
half. There is a need to strengthen public investment management (including public sector institutions, skills, and capacity) to achieve better prioritization, more efficient resource allocation, and effective implementation of environmentally sustainable infrastructure projects. According to the results of 60 conducted Public Investment Management Assessment (PIMA)-the IMF's tool to analyze the strength of public investment management practices-countries need to improve their project appraisal and selection capacities as well as maintenance funding which see the lowest scores in the public investment cycle. Strengthening these practices, which are key in kick-starting investment plans would go a long way in creating quality infrastructure

\section{Integrating climate change perspectives in public investment management would} enable countries to better implement environmentally sustainable infrastructure. In this regard, the IMF is also developing the PIMA Climate change Module (PIMA CC) with a particular focus on the resilience and sustainability aspects-PIMA CC integrates climate change issues into PIMA framework and help strengthen governments' capacity to address risks related to climate and natural disasters in public investment. Countries' capacity to deliver quality projects in a timely manner are essential if public investment is to boost growth and create jobs in both the short and long term. 


\section{References}

Global Commission on Adaptation. 2019. Adapt Now: A Global Call for Leadership on Climate Resilience.

Global Infrastructure Hub and Oxford Economics. 2017. Global Infrastructure Outlook. July 2017.

G20. 2019. G20 Principles for Quality Infrastructure Investment. July 2019.

IMF. 2019. Fiscal Monitor: How to Mitigate Climate Change. Washington D.C., October.

IMF. 2020. Fiscal Monitor: Policies for the Recovery. Washington D.C., October.

IMF. 2020. Fiscal Monitor. IDEAS to Respond to Weaker Growth. Washington D.C., April.

IMF. 2020. World Economic Outlook: A Long and Difficult Ascent. Washington, DC, October.

IMF Infrastructure Governance Portal: Infrastructuregovern.IMF.org

IPCC, 2014: Summary for Policymakers. In: Climate Change 2014: Mitigation of Climate Change. Contribution of Working Group III to the Fifth Assessment Report of the Intergovernmental Panel on Climate. Cambridge University Press, Cambridge, United Kingdom and New York, NY, USA.

Schwartz, G., Fouad, M., Hansen, T., and Verdier, G. (eds). 2020. Well Spent: How Strong Infrastructure Governance Can End Waste in Public Investment. Washington, DC: International Monetary Fund.

Swiss Re Institute and Global Infrastructure Facility. 2021. Closing the Infrastructure Gap: Mobilising Institutional Investment into Sustainable, Quality Infrastructure in Emerging Markets and Developing Economies.

Tong, D., Zhang, Q., Zheng, Y. et al. Committed emissions from existing energy infrastructure jeopardize $1.5^{\circ} \mathrm{C}$ climate target. Nature $572,373-377$ (2019).

World Bank. 2019. Lifelines: The Resilient Infrastructure Opportunity. World Bank. Washington D.C. 